Rizayusmanda, Kajian Normatif Tentang Proses Pelaksanaan Pembebanan Jaminan Fidusia Atas Jaminan Persediaan Barang Dan Piutang Dagang Di Dunia Perbankan, halaman 76-83

\title{
KAJIAN NORMATIF TENTANG PROSES PELAKSANAAN PEMBEBANAN JAMINAN FIDUSIA ATAS JAMINAN PERSEDIAAN BARANG DAN PIUTANG DAGANG DI DUNIA PERBANKAN
}

\author{
Rizayusmanda \\ Fakultas Hukum Universitas Palembang \\ e-mail: ryusmanda@yahoo.com
}

\begin{abstract}
Banking is an institution that is vulnerable to risks related to money. The banking position as a mediator that connects those with surplus and financial deficits, banks must maintain good relations with the two parties. Banking decisions must be moderate, namely considering the desires of both parties because without the two parties, banking activities are not running. But if you are not careful in disbursing loans, bad credit will occur, then to protect the money disbursed, the debtor must provide collateral to the bank. This paper is a normative legal research that is research aimed at written regulations relating to the procedure for carrying out fiduciary collateral for collateral in the form of inventory and trade receivables according to Fiduciary Law Number 42 of 1999, and the legal consequences if the collateral is in the form of inventory the goods and receivables are not processed by loading fiduciary and registering them to the Fiduciary Registration Office. In the implementation of Fiduciary Collateral Imposition, especially collateral for credit in the form of goods and trade receivables, as determined by law, by registering the Fiduciary Deed of Registration with the Fiduciary Registration Office Ministry of Law and Human Rights. For collateral for loans financed by banks, the Actions made under the hand or Notarial but not registered with the Fiduciary Deed of Registration at the Fiduciary Security Registration Office, do not get preferential rights and an executorial right guaranteed by the Fiduciary Guarantee Institute, and the Fiduciary Guarantee Agreement is only in the form of a Fiduciary Deed Registration Office. under the hand that has no executive power.
\end{abstract}

Keywords: Fiduciary Security; Account receivable; Banking

\begin{abstract}
ABSTRAK
Perbankan adalah lembaga yang rentan dengan risiko yang berkaitan dengan uang. Posisi perbankan sebagai mediasi yang menghubungkan mereka yang surplus dan deficit financial, perbankan harus menjaga hubungan baik dengan kedua pihak tersebut. Keputusan perbankan harus bersifat moderat yaitu mempertimbangkan keinginan kedua pihak karena tanpa kedua pihak, aktivitas perbankan tidak berjalan. Namun jika tidak hati-hati dalam menyalurkan pinjaman akan terjadi kredit macet, maka untuk melindungi uang yang dikucurkan debitur wajib memberikan jaminan kepada bank. Tulisan ini merupakan penelitian hukum normatif yaitu penelitian yang ditujukan pada peraturan-peraturan yang tertulis yang berhubungan dengan prosedur pelaksanaan pembebanan jaminan fidusia atas jaminan berupa persediaan barang dan piutang dagang menurut Undang-Undang Jaminan Fidusia Nomor 42 Tahun 1999, serta akibat hukumnya apabila jaminan berupa persediaan barang dan piutang tersebut tidak diproses dengan pembebanan fidusia dan pendaftarannya ke Kantor Pendaftaran Fidusia.Bahwa dalam pelaksanaan Pembebanan Jaminan Fidusia khususnya agunan kredit berupa persediaan barang dan piutang dagang, sebagaimana yang telah ditentukan oleh undang-undang yaitu dengan mendaftarkan Akta Jaminan Fidusia kepada Kantor Pendaftaran Fidusia - Kementerian Hukum dan Hak Asasi Manusia. Bagi agunan kredit yang dibiayai oleh pihak perbankan yang Aktanya
\end{abstract}


Rizayusmanda, Kajian Normatif Tentang Proses Pelaksanaan Pembebanan Jaminan Fidusia Atas Jaminan Persediaan Barang Dan Piutang Dagang Di Dunia Perbankan, halaman 76-83

dibuat dibawah tangan maupun Notarial namun tidak didaftarkan Akta Jaminan Fidusianya kepada Kantor Pendaftaran Jaminan Fidusia, maka tidak mendapat hak preferen dan hak eksekutorial yang dijamin oleh Lembaga Jaminan Fidusia, dan Perjanjian Jaminan Fidusia tersebut hanyalah berupa Akta dibawah tangan yang tidak mempunyai kekuatan eksekutorial.

Kata Kunci : Jaminan Fidusia; Piutang Dagang; Perbankan

I. PENDAhuluan

\section{A. Latar Belakang}

Perbankan di Indonesia mempunyai peranan yang sangat penting, salah satunya menjaga stabilitas moneter yang disebabkan atas kebijakannya terhadap simpanan masyarakat serta sebagai lalu lintas pembayaran. Bank sendiri merupakan suatu badan usaha yang tujuannya menghasilkan keuntungan atau laba. Ketika negara sedang melakukan proses pemulihan ekonomi, umumnya bank masih belum bisa optimal dalam menjalankan fungsi utamanya sebagai lembaga intermediasi keuangan yang menggambarkan rasio perbandingan jumlah kredit yang diberikan pada pihak ketiga (LDR/Loan to Deposit Ratio). Peranan intermediasi lembaga perbankan sangat berpengaruh pada pertumbuhan perekonomian suatu negara yakni ketika terjadi penurunan jumlah kredit yang disalurkan akibat sikap kehati-hatian dari pihak bank, secara tidak langsung akan terjadi perlambatan pertumbuhan ekonomi di negara yang bersangkutan ${ }^{1}$.

Pada intinya bank dapat didefinisikan sebagai suatu badan usaha yang menghimpun dana dari masyarakat dalam bentuk simpanan dan menyalurkannya kepada masyarakat kembali dalam rangka meningkatkan taraf hidup rakyat banyak, sesuai dengan undang-undang Perbankan Nomor 7 Tahun 1992 tentang Perbankan yang telah diubah menjadi undang-undang Nomor 10 Tahun 1998 (selanjutnya peneliti tulis menjadi UUP No.10 Tahun 1998),

\footnotetext{
${ }^{1}$ (http:IIdirektorritraining.com), "Peranan Bank Dalam Perekonomian Suatu Negara”, diakses tanggal 27 Desember 2018.
}

bank didefinisikan sebagai perusahaan yang bergerak dibidang jasa dengan kegiatan pokoknya yang mempunyai 3 (tiga) fungsi pokok, yaitu:

1. Menerima penyimpanan dana masyarakat dalam berbagai bentuk.

2. Menyalurkan dana tersebut dalam bentuk kredit kepada masyarakat untuk mengembangkan usaha.

3. Melaksanakan berbagai jasa dalam kegiatan perdagangan dan pembayaran dalam negeri maupun luar negeri, serta berbagai jasa lainnya dibidang keuangan, diantaranya inkaso transfer, traveller cheque, credit card, safe deposit box, jual beli surat berharga dan sebagainya. ${ }^{2}$

Perbankan adalah lembaga yang paling rentan atau berdekatan dengan risiko, khususnya risiko yang berkaitan dengan uang (money). Posisi perbankan sebagai mediasi yaitu pihak yang menghubungkan mereka yang surplus dan deficit financial telah menempatkan perbankan harus selalu menjaga hubungan baik dengan kedua pihak tersebut. Keputusan perbankan harus selalu bersifat moderat yaitu mempertimbangkan keinginan dari kedua pihak tersebut karena tanpa kedua pihak tersebut perbankan tidak bisa menjalankan aktifitas secara maksimal. Dalam artian jika perbankan memiliki tingkat likuiditas yang tinggi karena ia memiliki financial yang begitu surplus itu juga dianggap tidak baik, karena ia tidak menjalankan fungsinya sebagai agent of development. Namun

\footnotetext{
${ }^{2}$ Ikatan Bankir Indonesia, "Mengelola Bank Komersial”, PT. Gramedia Pustaka Utama, Jakarta, 2014, hlm.63.
} 
sebaliknya jika ia tidak hati-hati dalam menyalurkan pinjaman maka perbankan sendiri yang akan menerima akibatnya yaitu salah satu timbulnya kredit macet, ${ }^{3}$ maka untuk melindungi uang yang dikucurkan lewat kredit dari risiko kerugian, maka pihak bank membuat pagar pengaman. Dalam kondisi sebaik apapun atau analisis sebaik mungkin, resiko kredit macet tidak dapat dihindari. Pagar pengaman yang dibuat biasanya berupa jaminan yang harus disediakan debitur.

Pada umumnya dalam rangka mengamankan pemberian kreditnya, bank menuntut nasabah debitur untuk memberikan jaminan kebendaan (agunan). Jaminan kebendaan (agunan) pemberian kredit bank tersebut pada hakikatnya berfungsi untuk menjamin kepastian akan pelunasan utang debitur bila debitur cidera janji atau dinyatakan pailit. Dengan adanya jaminan pemberian kredit tersebut, akan memberikan jaminan perlindungan, baik bagi keamanan dan kepastian hukum kreditur bahwa kreditnya akan tetap kembali walaupun mungkin nasabah debiturnya cidera janji, yakni dengan cara mengeksekusi benda yang menjadi objek jaminan kredit bank yang bersangkutan. Selain itu, bank dituntut untuk dapat membuat suatu desain hubungan hukum yang baik dengan calon nasabah debiturnya, sehingga tercipta sinergi kerja yang baik antara kreditur (bank) dan nasabah debiturnya. Apabila nasabah debiturnya dinyatakan cidera janji, bank dengan mudah mengeksekusi objek benda yang menjadi jaminan yang telah diberikan nasabah debitur berdasarkan desain hubungan hukum yang telah dibuat sebelumnya. Dengan demikian, jaminan kebendaan (agunan) dalam pemberian kredit ini menjadi sarana yang ampuh

\footnotetext{
${ }^{3}$ Irham Fahmi, "Bank \& Lembaga Keuangan Lainnya, Teori dan Aplikasi”, CV. Alfabeta, Bandung, 2014, hlm.72.
}

untuk mengamankan pemberian kredit. Untuk itulah diadakan lembaga dan ketentuan hukum jaminan. Selain itu, jaminan kredit dimaksudkan haruslah juga secured, artinya jaminan kredit tersebut dapat diadakan pengikatan secara yuridis sempurna, sesuai dengan hukum dan perundang-undangan yang berlaku. Apabila dikemudian hari terjadi wanprestasi dari debiturnya, bank telah mempunyai alat bukti sempurna dan lengkap untuk menjalankan suatu tindakan hukum. ${ }^{4}$

Kredit yang berasal dari kata Italia, Credere yang artinya kepercayaan, yaitu kepercayaan dari kreditur bahwa debiturnya akan mengembalikan pinjaman beserta bunganya sesuai dengan perjanjian kedua belah pihak, tegasnya kreditur percaya bahwa kredit itu tidak akan macet ${ }^{5}$.

Kredit adalah perjanjian pinjammeminjam, sebagaimana dimaksud dalam Pasal 1754 KUHPerdata, bahwa" Pinjammeminjam ialah persetujuan dengan mana pihak yang satu memberikan kepada pihak yang lain suatu jumlah tertentu barangbarang yang menghabis karena pemakaian, dengan syarat bahwa pihak yang belakangan ini akan mengembalikan sejumlah yang sama dari macam dan keadaan yang sama pula".

Kredit adalah hak untuk menerima pembayaran atau kewajiban untuk melakukan pembayaran pada waktu diminta atau pada waktu yang akan datang karena penyerahan barang-barang sekarang

Sedangkan menurut UUP No.10 tahun 1998, sesuai Pasal 1 yang dimaksud dengan Kredit adalah Penyediaan uang

\footnotetext{
${ }^{4}$ Rachmadi Usman, “Hukum Jaminan Keperdataan”, PT. Sinar Grafika, Jakarta, 2016, hlm.54.

${ }^{5}$ Malayu S.P. Hasibuan, "Dasar-Dasar Perbankan", PT. Bumi Aksara, Jakarta, 2015, hlm.32.

${ }^{6}$ Bymont P. Kent. Dikutip oleh Drs. Thomas Suyatno, dkk, 1990 : 15.
} 
Rizayusmanda, Kajian Normatif Tentang Proses Pelaksanaan Pembebanan Jaminan Fidusia Atas Jaminan Persediaan Barang Dan Piutang Dagang Di Dunia Perbankan, halaman 76-83

atau tagihan yang dapat dipersamakan dengan itu, berdasarkan persetujuan atau kesepakatan pinjam meminjam antara bank dengan pihak lain yang mewajibkan pihak peminjam untuk melunasi hutang setelah jangka waktu tertentu dengan pemberian bunga. Berdasarkan definisi diatas dapat dipahami bahwa dalam pemberian kredit, yang menjadi debitur adalah nasabah bank dan yang menjadi kreditur adalah pihak bank.

Secara umum jenis kredit berdasarkan tujuan penggunaannya dibedakan menjadi 3 (tiga) bentuk, yaitu sebagai berikut:

1. Kredit Modal Kerja (KMK) adalah kredit yang dipergunakan untuk keperluan menambah modal kerja perusahaan, seperti pembelian bahan baku, biaya produksi, pemasaran dan lain-lain sebagai contoh KMK untuk pembiayaan persediaan.

2. Kredit Investasi adalah fasilitas kredit yang diberikan untuk membiayai kebutuhan barang-barang modal dalam rangka rehabilitasi, modernisasi, perluasan, pendirian proyek baru, dan/atau kebutuhan lainnya terkait investasi.

3. Kredit Konsumtif adalah kredit yang diberikan kepada perseorangan yang dapat diajukan secara persorangan, kelompok, atau melalui perusahaan untuk keperluan konsumtif dan/atau keperluan serbaguna, termasuk pemberian kartu kredit, dan lain-lain. ${ }^{7}$

Pada dasarnya, pemberian kredit oleh bank diberikan kepada siapa saja yang memiliki kemampuan untuk membayar kembali dengan syarat melalui suatu perjanjian utang-piutang di antara kreditur dan debitur. ${ }^{8}$

${ }^{7}$ Ikatan Bankir Indonesia, Op.Cit, hlm. 84.

${ }^{8}$ Gunawan Widjaja dan Ahmad Yani, "Jaminan

Fidusia”, PT.Raja Grafindo Persada, Jakarta, 2000, hlm. 31.
Menurut Pasal 1131 KUHPerdata menyebutkan bahwa jaminan adalah "segala kebendaan milik si berutang, baik yang bergerak maupun yang tak bergerak, baik yang sudah ada maupun yang baru akan ada dikemudian hari, menjadi tanggungan untuk segala perikatannya perseorangan". Pasal 1131 KUHPerdata menentukan suatu kewajiban bagi debitur untuk memberikan jaminan kepada kreditur atas utang yang telah diterimanya, tanpa adanya jaminan yang ditentukan secara khusus maka segala harta kekayaan debitur yang telah ada maupun yang akan ada secara otomatis menjadi jaminan ketika orang tersebut membuat perjanjian utang meskipun hal tersebut tidak dinyatakan secara tegas dalam perjanjian .

Pemberian jaminan dalam suatu perjanjian utang-piutang maupun perjanjian kredit sangat diperlukan kreditur, karena kreditur mempunyai kepentingan untuk memastikan debitur akan benar-benar memenuhi kewajibannya membayar utang. Jaminan akan memastikan jika debitur wanprestasi, benda yang dijaminkan itu akan dilelang (dijual) dan uang hasil penjualan kebendaan tertentu tersebut akan digunakan untuk pelunasan seluruh atau sebagian dari pinjaman atau utang debitur kepada kreditur. Dengan kata lain, jaminan ini berfungsi sebagai sarana untuk menjamin pelunasan pinjaman atau utang debitur apabila debitur wanprestasi sebelum pinjaman jatuh tempo atau utang tersebut berakhir. ${ }^{9}$

Jaminan secara garis besar ada 2 (dua) macam, yakni jaminan perseorangan dan jaminan kebendaan, dengan pengikatan agunan, yaitu:

1. Pengikatan atas hak kebendaan yaitu Hak Tanggungan, Hipotek, Gadai

\footnotetext{
${ }^{9}$ Yurizal, "Aspek Pidana dalam Undang-Undang No.42 Tahun 1999 Tentang Jaminan Fidusia”, Media Nusa Creative, Jakarta, 2015, hlm.14.
} 
(pand), Fidusia \& Hak jaminan atas resi gudang.

2. Pengikatan atas hak perorangan yaitu: jaminan pribadi (borgtough) dan jaminan perorangan (corporate guarantee) ${ }^{10}$

Salah satu jenis fasilitas kredit yang disalurkan oleh perbankan yaitu fasilitas Kredit Modal Kerja (KMK) yang tujuannya dalam rangka untuk membiayai kegiatan usaha debitur yang sumber pembayarannya berasal dari usaha yang dibiayai, antara lain dipergunakan untuk pembelian persediaan (inventory), barang dagangan, bahan baku, biaya-biaya produksi, dan modal kerja untuk operasional lainnya. Persediaan barang dagang/inventory dan piutang dagang tersebut merupakan agunan utama yang diberikan debitur kepada phak bank, agar persediaan barang dan piutang dagang dapat dialihkan kepemilikannya kepada bank apabila debitur wanprestasi atau default, maka pihak bank agar melakukan proses pengikatannya sebagaimana yang telah diatur sesuai dengan peraturan perundang-undangan Republik Indonesia yaitu dengan pengikatan jaminan Fidusia.

Berdasarkan uraian diatas, maka peneliti tertarik untuk mengungkapkan dalam suatu penelitian yang peneliti beri judul: "KAJIAN NORMATIF TENTANG PROSES PELAKSANAAN PEMBEBANAN JAMINAN FIDUSIA ATAS JAMINAN PERSEDIAAN BARANG DAN PIUTANG DAGANG DI DUNIA PERBANKAN"

\section{B. Permasalahan}

Peneliti telah mengidentifikasi beberapa permasalahan yaitu bagaimanakah prosedur pelaksanaan pembebanan jaminan fidusia atas jaminan berupa persediaan barang dan piutang

\footnotetext{
${ }^{10}$ Ikatan Bankir Indonesia, Mengenal Operasional Perbankan 1, PT. Gramedia Pustaka Utama, 2015
}

dagang menurut UU Nomor 42 Tahun 1999 tentang Jaminan Fidusia ?, serta bagaimana pula akibat hukumnya apabila jaminan berupa persediaan barang dan piutang tersebut tidak diproses dengan pembebanan fidusia dan pendaftarannya ke Kantor pendaftaran fidusia?

\section{Metodologi}

\section{Pendekatan Permasalahan}

Pembahasan permasalahan pada penelitian ini dilakukan dengan pendekatan hukum normatif dalam arti dilakukan dengan mengkaji terhadap peraturan perundangan yang berhubungan dengan permasalahan dalam penelitian ini, di samping itu dilakukan pendekatan lapangan untuk memperoleh informasi sebagai penunjang.

\section{2 . Data dan Sumber Data}

Dalam penelitian ini digunakan data sekunder yang terdiri dari:

a. Bahan hukum primer, yaitu bahan berupa peraturan perundang-undangan yang berhubungan dengan permasalahan.

b. Bahan hukum sekunder, yaitu bahan yang memberikan penjelasan mengenai bahan hukum primer berupa karya ilmiah yang ada relevansinya dengan masalah-masalah yang akan diteliti.

c. Bahan hukum tersier, yaitu bahan-bahan yang memberikan informasi tentang bahan hukum primer dan sekunder, berupa kamus hukum, kamus bahasa Indonesia, media masa dan internet.

\section{Analisis Data}

Data yang dikumpulkan dan diperoleh dalam penelitian ini dianalisis dengan metode kualitatif secara deskriptif dalam arti diuraikan dalam bentuk kata-kata dan dihubungkan secara sistematis guna menarik kesimpulan dalam menggambarkan jawaban permasalahan.

\section{HASIL PENELITIAN DAN PEMBAHASAN}

\section{A. Prosedur Pelaksanaan Pembebanan Jaminan Fidusia Atas Jaminan Berupa}




\section{Persediaan Barang dan Piutang Bagang Menurut Undang-Undang Nomor 42 Tahun 1999 Tentang Jaminan Fidusia}

Prosedur Pelaksanaan Pembebanan Jaminan Fidusia harus dilaksanakan pada hari yang sama dengan pembuatan Perjanjian Kredit, dimana pembebanan Jaminan Fidusia dilaksanakan dengan menandatanganan Akta Jaminan Fidusia yang akan ditanda tangani oleh calon debitur setelah menandatangani Perjanjian Kredit sebagai perjanjian pokok yang dibuat oleh Notaris rekanan yang ditunjuk dan disetujui oleh Calon Debitur, dengan tahapan sebagai berikut:

- Menerima, mencatat surat dari Business Unit untuk permintaan pembuatan Pembebanan Jaminan Fidusia.

- Memeriksa dokumen laporan rincian persediaan barang/piutang dagang antara lain dibuat diatas surat dengan kop perusahaan, tanggal dokumen dan ditanda tangani diatas materai Rp.6.000,(enam ribu rupiah) oleh pengurus yang berwenang sesuai dengan anggaran dasar perusahaan.

- Membuat surat order/permintaan pembebanan Jaminan Fidusia kepada Notaris rekanan yang ditunjuk dengan dilampiri dokumen terkait yaitu akta perusahaan, identitas debitur yang berhak mewakili perusahaan sesuai dengan anggaran perusahaan serta dokumen rincian persediaan barang dan piutang dagang.

Surat order minimal memuat keterangan sebagai berikut:

Nomor Registrasi Perjanjian Kredit.

$\checkmark$ Nilai Limit Kredit \& Jangka Waktu Kredit.

$\checkmark$ Jenis dan Nilai Pembebanan Fidusia Pengikatan Objek Agunan Kredit (Hak Tanggungan/Fidusia).

$\checkmark$ Pihak yang bertanda tangan sesuai kewenangan para pihak (bank/calon debitur).
Jangka waktu Service Level Agreement (SLA).

- Menanda tangani Perjanjian Kredit oleh para pihak (bank/calon debitur) dihadapan Notaris dan saksi.

- Menanda tangani Akta Jaminan Fidusia sebelumnya proses penanda tanganan pihak bank, agar memastikan dengan memeriksa terlebih dahulu bahwa data telah sesuai dan telah dimasukan kedalam Akta Jaminan Fidusia antara lain sebagai berikut:

$\checkmark \quad$ Waktu dan tempat
dilaksanakan
Penandatanganan
Jaminan Fidusia.
$\checkmark \quad$ Para pihak (bank/calon
debitur) yang menanda
tangani Akta Jaminan Fidusia
telah sesuai dengan
kewenangan perusahaan.
$\checkmark \quad$ Nomor Registrasi Perjanjian
Kredit dan Nomor Perjanjian
Kredit Notarial yang fasilitas
kreditnya dijamin oleh
Jaminan Fidusia.
Nilai Pembebanan Jaminan
$\checkmark \quad$ Objek Jaminan Fidusia.
Pihak Notaris melaksanakan proses
pelaporan Akta Jaminan Fidusia
melalui website Kementerian
Hukum dan Hak Asasi
Manusia/Kantor Pendaftaran
Fidusia.

\section{Pendaftaran Pembebanan Jaminan Fidusia.} Persediaan barang/stock dan piutang yang dibiayai oleh bank secara rasio agunan merupakan agunan utama yang diserahkan oleh calon debitur sehingga bank harus memastikan bahwa persediaan barang/piutang dagang tersebut dapat menjadi sumber 
pelunasan, apabila kredit yang disalurkan kepada debitur mengalami gagal bayar (default), sehingga bank wajib melaksanakan pengikatan secara fidusia dan mendaftarkannya ke Kantor Pendaftaran Fidusia sebagaimana yang telah ditentukan oleh undang-undang.

Untuk menghindari terjadi sesuatu yang dapat membatalkan atau tidak dapatnya bank melaksanakan eksekusi dikarenakan suatu kesalahan atau kelalaian dari pihak bank, maka hal-hal yang tersebut dibawah ini yang harus menjadi perhatian oleh pihak bank yang tercantum pada Akta Jaminan Fidusia maupun Sertifikat Jaminan Fidusia, antara lain:

1. Pemberi dan Penerima Fidusia ( sesuai dengan undang-undang).

2. Rincian stock sesuai dengan tujuan pembiayaan.

3. Nilai objek yang dibiayai.

4. Nilai pengikatan fidusia.

5. Lokasi objek agunan (apabila ada double financing dari bank lain).

6. Dasar pengikatan yaitu Nomor, Tanggal, Limit Perjanjian Kredit.

\section{B. Akibat Hukum Jika Jaminan Berupa Persediaan Barang dan Piutang Dagang Tidak Diproses Dengan Pembebanan Fidusia dan Pendaftarannya Ke Kantor Pendaftaran Fidusia}

Peraturan tentang pendaftaran

Jaminan Fidusia awalnya dilaporkan secara manual sesuai Peraturan Pemerintah Nomor 86 Tahun 2000 tentang Tata Cara Pendaftaran Jaminan Fidusia dan Biaya Pembuatan Akta Jaminan Fidusia. Dalam Upaya mempercepat proses pendaftaran Fidusia, Kementerian Hukum dan Hak Asasi Manusia Republik Indonesia (Kemenkumham) melalui Surat Edaran Direktorat Jenderal Administrasi Hukum Umum (Ditjen AHU) tertanggal 5 Maret 2013, Nomor AHU-06.OT.03.01 Tahun 2013 mengenai Pemberlakuan Sistem Administrasi Pendaftaran Jaminan Fidusia secara Elektronik (Online System) maka sejak tanggal 05 Maret 2013 dimulainya Pendaftaran Jaminan Fidusia secara online. Keputusan tersebut telah dituangkan ke dalam Peraturan Pemerintah (PP) Nomor 21 Tahun 2015 tertanggal 16 April 2015, sekaligus menggantikan Peraturan Pemerintah (PP) Nomor 86 Tahun 2000. Sehingga Kantor Pendaftaran Fidusia di seluruh Indonesia dalam menjalankan tugas dan fungsinya tidak lagi menerima permohonan pendaftaran jaminan fidusia secara manual, dimana pelaksanaan pendaftaran sampai dengan pencetakan Sertifikat Jaminan Fidusia dilaksanakan oleh Kantor Pendaftaran Fidusia. Dengan berlakunya peraturan secara online tersebut maka pendaftaran sampai dengan pencetakan Sertifikat Jaminan Fidusia dapat dilakukan langsung oleh Notaris.

Penggunaan system online dilakukan sebagai wujud dari pelaksanaan Pasal 14 Ayat 1 UUJF No 42 Tahun 1999 agar pelaksanaannya menjadi efektif dan efisien, yaitu penerimaan Sertifikat Jaminan Fidusia dapat diterima oleh Penerima Fidusia pada tanggal yang sama dengan tanggal permohonan pendaftaran. Dengan adanya system online, maka sertifikat jaminan fidusia dapat dicetak dalam waktu 1 hari (one day service $)^{11}$

Melihat ketentuan diatas, sebenarnya jika kreditur dalam hal ini pihak bank tersebut membuat perjanjian kedalam akta Notarial (Akta Notaris) dan didaftarkan di Kantor Pendaftaran Fidusia maka akan memperoleh Sertifikat Jaminan Fidusia yang memuat irahirah " DEMI KEADILAN BERDASARKAN KETUHANAN YANG MAHA ESA” dengan sertifikat jaminan fidusia itulah kreditur/penerima fidusia secara serta merta mempunyai hak eksekusi langsung (parate executie) tanpa memerlukan putusan

11 http://Irmadevita. Com, diakses tanggal 11 Mei 2018 
Pengadilan karena kekuatan hukum sertifikat tersebut sama dengan putusan pengadilan yang sudah mempunyai kekuatan hukum yang tetap $^{12}$.

Setelah mengetahui dasar dan ketentuan tersebut diatas, akibat hukum dari Perjanjian fidusia yang dibuat tanpa menggunakan bentuk Akta Notariil dan tidak didaftarkan, maka perjanjian dengan jaminan Fidusia tersebut hanyalah berupa akta dibawah tangan yang tidak mempunyai kekuatan eksekutorial untuk mengeksekusi langsung barang yang ada dalam penguasaan konsumen.

\section{PENUTUP}

\section{A. Kesimpulan}

Berdasarkan uraian tersebutdapat disimpulkan dalam pelaksanaan Pembebanan Jaminan Fidusia khususnya agunan kredit berupa persediaan barang dan piutang dagang, sebagaimana yang telah ditentukan oleh undang-undang yaitu dengan mendaftarkan Akta Jaminan Fidusia kepada Kantor Pendaftaran Fidusia - Kementerian Hukum dan Hak Asasi Manusia. Bagi agunan kredit yang dibiayai oleh pihak perbankan yang Aktanya dibuat dibawah tangan maupun Notarial namun tidak didaftarkan Akta Jaminan Fidusianya kepada Kantor Pendaftaran Jaminan Fidusia maka tidak mendapat hak preferen dan hak eksekutorial yang dijamin oleh Lembaga Jaminan Fidusia, dan Perjanjian Jaminan Fidusia tersebut hanyalah berupa Akta dibawah tangan yang tidak mempunyai kekuatan eksekutorial untuk mengeksekusi langsung barang yang ada dalam penguasaan Debitur .

\section{B. Saran-Saran}

1. Saat ini sudah suatu keniscayaan bagi pemerintah untuk membuat berbagai macam peraturan perundang-undangan yang berkaitan dengan hak-hak konsumen, dimana substansi didalam peraturan perundang-undangan tersebut harus

\footnotetext{
${ }^{12}$ Penjelasan UU No.42 Tahun 1999 pasal 15 ayat 2
}

mengatur soal keseimbangan antara hak dan kewajiban konsumen dengan hak dan kewajiban produsen, sehingga terjadi keseimbangan diantara kedua belah pihak.

2. Pemahaman pelaku usaha dan masyarakat dalam hal Lembaga Penjaminan Fidusia masih rendah, maka perlu diadakan sosialisasi yang lebih intensif bagi pihakpihak yang berkepentingan terhadap lembaga ini, khususnya pelaku usaha yang bergerak dibidang perbankan, konsumen itu sendiri dan aparat penegak hukum serta pihak-pihak lain yang terkait

\section{DAFTAR PUSTAKA}

Gunawan Widjaja dan Ahmad Yani, Jaminan Fidusia, Jakarta: PT. Raja Grafindo Persada, 2000

Ikatan Bankir Indonesia, Mengelola Bank Komersial, PT. Gramedia Pustaka Utama, 2014

Operasional Perbankan 2, PT.
Gramedia Pustaka Utama, 2014

Irham Fahmi, Bank \& Lembaga Keuangan Lainnya, Teori dan aplikasi, CV. Alfabeta Bandung, 2014

Malayu S.P. Hasibuan, Dasar-dasar Perbankan, PT. Bumi Aksara, Jakarta 2015

Rachmadi Usman, Hukum Jaminan Keperdataan, PT. Sinar Grafika, 2016

Yurizal, Aspek Pidana dalam Undang-undang No.42 Tahun 1999 Tentang Jaminan Fidusia, Media Nusa Creative, 2015 http:Idirektorritraining.com, Peranan Bank dalam perkonomian suatu Negara, diakses tgl 27 Desember 2018 